\title{
Two New Sesquiterpenoids from Solanum lyratum with Cytotoxic Activities
}

\author{
Yan ReN, ${ }^{a}$ Li SHen, ${ }^{b}$ De-Wu ZhANG, ${ }^{a}$ and Sheng-Jun DAI ${ }^{*}, a$ \\ ${ }^{a}$ School of Pharmaceutical Science, Yantai University; Yantai 264005, People's Republic of China: and ${ }^{b}$ Key Laboratory of \\ Marine Drugs, Chinese Ministry of Education, Institute of Marine Drug and Food; Qingdao 266003, People's Republic of \\ China. Received November 1, 2008; accepted December 25, 2008; published online January 19, 2009
}

Two new sesquiterpenoids, lyratol C (1) and lyratol D (2), together with two known sesquiterpenoids, dehydrovomifoliol (3) and blumenol A (4), were isolated from the whole plant of Solanum lyratum. Their structures were established by spectroscopic analyses. In vitro, the four compounds showed significant cytotoxic activities against three human cancer cell lines, namely, HONE-1 nasopharyngeal, KB oral epidermoid carcinoma, and HT29 colorectal carcinoma cells, and gave $\mathrm{IC}_{50}$ values in the range $3.7-8.1 \mu \mathrm{M}$.

Key words Solanum lyratum; Solanaceae; sesquiterpenoid; lyratol C; lyratol D; cytotoxic activity

The whole plant of Solanum lyratum ThunB (Solanaceae) is a renowned traditional Chinese medicine. Extracts of this plant and its constituents were reported to exhibit a wide spectrum of biological activities including antitumor, antibacterium, and anti-inflammation. ${ }^{1-3)}$ As part of our search for antitumor compounds, the EtOH extract of $S$. lyratum was successively partitioned with $\mathrm{CHCl}_{3}$, EtOAc, and $n$-BuOH. The $\mathrm{CHCl}_{3}$ fraction was sequentially subjected to column chromatography over silica gel, silica gel RP-18, and Sephadex LH-20 to give two new sesquiterpenoids, named lyratol C (1) and lyratol D (2), and two known sesquiterpenoids, dehydrovomifoliol (3) ${ }^{4)}$ and blumenol A (4). ${ }^{5)}$ By means of chemical methods and spectroscopic analyses, the structures of the two new compounds were established. In addition, the four isolated compounds were screened for cytotoxicity against three tumor cell lines (HONE-1 nasopha- ryngeal, KB oral epidermoid carcinoma, and HT29 colorectal carcinoma cells), with $\mathrm{IC}_{50}$ values being in the range $3.7-8.1 \mu \mathrm{M}$. Herein we report on the isolation and structure elucidation as well as the evaluation of cytotoxic effects of these four compounds.

\section{Results and Discussion}

Compound 1 was obtained as a colorless prismatic crystal. The molecular formula was established as $\mathrm{C}_{15} \mathrm{H}_{26} \mathrm{O}_{4}$ by HRFAB mass spectroscopy, which displayed a quasi-molecular ion peak at $m / z 271.1909[\mathrm{M}+\mathrm{H}]^{+}$. The IR spectrum showed absorption bands at 3405 (br) and $1651 \mathrm{~cm}^{-1}$, which were assignable to hydroxyl and double bond groups. The ${ }^{1} \mathrm{H}-\mathrm{NMR}$ spectrum of 1 showed signals corresponding to two tertiary methyls $\left(\delta_{\mathrm{H}} 1.06,3 \mathrm{H}, \mathrm{s}, \mathrm{H}-14 ; 1.48,3 \mathrm{H}, \mathrm{s}, \mathrm{H}-13\right)$, two olefinic protons $\left(\delta_{\mathrm{H}} 4.91,1 \mathrm{H}, \mathrm{s}, \mathrm{H}-15 \mathrm{a} ; 4.71,1 \mathrm{H}, \mathrm{s}, \mathrm{H}-15 \mathrm{~b}\right)$,

Table 1. NMR Data of Compounds $\mathbf{1}$ and $\mathbf{2}^{a, b)}$

\begin{tabular}{|c|c|c|c|c|c|c|}
\hline \multirow{2}{*}{ No. } & \multicolumn{2}{|l|}{$1\left(\mathrm{C}_{5} \mathrm{D}_{5} \mathrm{~N}\right)$} & \multicolumn{2}{|l|}{$2\left(\mathrm{CDCl}_{3}\right)$} & \multicolumn{2}{|l|}{$2\left(\mathrm{DMSO}-d_{6}\right)$} \\
\hline & $\delta_{\mathrm{H}}$ & $\delta_{\mathrm{C}}$ & $\delta_{\mathrm{H}}$ & $\delta_{\mathrm{C}}$ & $\delta_{\mathrm{H}}$ & $\delta_{\mathrm{C}}$ \\
\hline 1 & $3.53(\mathrm{~d}, 9.0)$ & $84.5 \mathrm{CH}$ & & & & \\
\hline 2 & $4.08(\mathrm{~m})$ & $71.8 \mathrm{CH}$ & & $175.8 \mathrm{C}$ & & $175.1 \mathrm{C}$ \\
\hline 3 & $\begin{array}{l}2.92(\mathrm{dd}, 5.5,12.6, \mathrm{H}-3 \alpha) \\
2.45(\mathrm{dd}, 12.6,11.9, \mathrm{H}-3 \beta)\end{array}$ & $44.3 \mathrm{CH}_{2}$ & $\begin{array}{l}2.40(\mathrm{dd}, 3.9,18.7, \mathrm{H}-3 \mathrm{a}) \\
2.41(\mathrm{dd}, 10.8,18.7, \mathrm{H}-3 \mathrm{~b})\end{array}$ & $34.5 \mathrm{CH}_{2}$ & $\begin{array}{l}2.54(\mathrm{dd}, 4.5,18.1, \mathrm{H}-3 \alpha) \\
2.17(\mathrm{dd}, 11.0,18.1, \mathrm{H}-3 \beta)\end{array}$ & $34.0 \mathrm{CH}_{2}$ \\
\hline 4 & & $149.0 \mathrm{C}$ & $2.42(\mathrm{~m})$ & $46.1 \mathrm{CH}$ & $2.35(\mathrm{~m}, \mathrm{H}-4 \beta)$ & $45.2 \mathrm{CH}$ \\
\hline 5 & $1.95(\mathrm{dd}, 10.5,3.5)$ & $48.6 \mathrm{CH}$ & & $86.7 \mathrm{C}$ & & $86.3 \mathrm{C}$ \\
\hline 6 & $\begin{array}{l}1.59(\mathrm{~m}, \mathrm{H}-6 \alpha) \\
1.97(\mathrm{~m}, \mathrm{H}-6 \beta)\end{array}$ & $25.2 \mathrm{CH}_{2}$ & $\begin{array}{l}2.63(\mathrm{dd}, 5.1,14.5, \mathrm{H}-6 \mathrm{a}) \\
2.69(\mathrm{dd}, 11.6,14.5, \mathrm{H}-6 \mathrm{~b})\end{array}$ & $27.8 \mathrm{CH}_{2}$ & $\begin{array}{l}2.64(\mathrm{dd}, 4.4,14.2, \mathrm{H}-6 \mathrm{a}) \\
2.51(\mathrm{dd}, 11.3,14.2, \mathrm{H}-6 \mathrm{~b})\end{array}$ & $27.2 \mathrm{CH}_{2}$ \\
\hline 7 & $1.99(\mathrm{~m})$ & $45.0 \mathrm{CH}$ & & $127.7 \mathrm{C}$ & & $126.4 \mathrm{C}$ \\
\hline 8 & $\begin{array}{l}1.73(\mathrm{~m}, \mathrm{H}-8 \alpha) \\
2.15(\mathrm{~m}, \mathrm{H}-8 \beta)\end{array}$ & $21.5 \mathrm{CH}_{2}$ & & $137.5 \mathrm{C}$ & & $137.0 \mathrm{C}$ \\
\hline 9 & $\begin{array}{l}2.51(\mathrm{~m}, \mathrm{H}-9 \alpha) \\
1.37(\mathrm{~m}, \mathrm{H}-9 \beta)\end{array}$ & $38.1 \mathrm{CH}_{2}$ & $6.52(\mathrm{~s})$ & $115.5 \mathrm{CH}$ & $6.41(\mathrm{~s})$ & $115.1 \mathrm{CH}$ \\
\hline 10 & & $40.0 \mathrm{C}$ & & $153.7 \mathrm{C}$ & & $154.9 \mathrm{C}$ \\
\hline 11 & & $74.2 \mathrm{C}$ & $6.52(\mathrm{~s})$ & $115.5 \mathrm{CH}$ & $6.41(\mathrm{~s})$ & $115.1 \mathrm{CH}$ \\
\hline 12 & $\begin{array}{l}4.01(\mathrm{~d}, 10.7, \mathrm{H}-12 \mathrm{a}) \\
3.95(\mathrm{~d}, 10.7, \mathrm{H}-12 \mathrm{~b})\end{array}$ & $69.0 \mathrm{CH}_{2}$ & & $137.5 \mathrm{C}$ & & $137.0 \mathrm{C}$ \\
\hline 13 & $1.48(\mathrm{~s}, 3 \mathrm{H})$ & $22.0 \mathrm{CH}_{3}$ & $1.42(\mathrm{~s}, 3 \mathrm{H})$ & $21.6 \mathrm{CH}_{3}$ & $1.35(\mathrm{~s}, 3 \mathrm{H})$ & $21.3 \mathrm{CH}_{3}$ \\
\hline 14 & $1.06(\mathrm{~s}, 3 \mathrm{H})$ & $11.9 \mathrm{CH}_{3}$ & $1.55(\mathrm{~s}, 3 \mathrm{H})$ & $27.0 \mathrm{CH}_{3}$ & $1.47(\mathrm{~s}, 3 \mathrm{H})$ & $26.5 \mathrm{CH}_{3}$ \\
\hline 15 & $\begin{array}{l}4.91(\mathrm{~s}, 1 \mathrm{H}, \mathrm{H}-15 \mathrm{a}) \\
4.71(\mathrm{~s}, 1 \mathrm{H}, \mathrm{H}-15 \mathrm{~b})\end{array}$ & $107.8 \mathrm{CH}_{2}$ & $2.26(\mathrm{~s}, 3 \mathrm{H})$ & $20.4 \mathrm{CH}_{3}$ & $2.20(\mathrm{~s}, 3 \mathrm{H})$ & $20.0 \mathrm{CH}_{3}$ \\
\hline 16 & & & $2.26(\mathrm{~s}, 3 \mathrm{H})$ & $20.4 \mathrm{CH}_{3}$ & $2.20(\mathrm{~s}, 3 \mathrm{H})$ & $20.0 \mathrm{CH}_{3}$ \\
\hline
\end{tabular}

a) Chemical shift values were in ppm and $J$ values (in $\mathrm{Hz}$ ) were presented in parentheses. $\quad$ b) The assignments were based on $\mathrm{HMQC}$, $\mathrm{HMBC}$, and ${ }^{1} \mathrm{H}-{ }^{1} \mathrm{H}$ COSY experiments. 

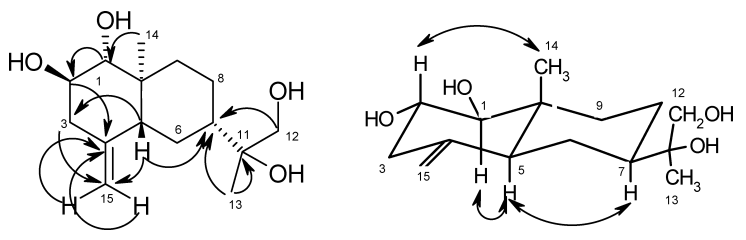

Fig. 1. Key HMBC and ROESY Correlations of $\mathbf{1}$

two oxygenated methine protons $\left(\delta_{\mathrm{H}} 3.53,1 \mathrm{H}, \mathrm{d}, J=9.0 \mathrm{~Hz}\right.$, $\mathrm{H}-1 ; 4.08,1 \mathrm{H}, \mathrm{m}, \mathrm{H}-2)$, and an oxygenated methylene $\left(\delta_{\mathrm{H}}\right.$ $4.01,1 \mathrm{H}, \mathrm{d}, J=10.7 \mathrm{~Hz}, \mathrm{H}-12 \mathrm{a} ; 3.95,1 \mathrm{H}, \mathrm{d}, J=10.7 \mathrm{~Hz}, \mathrm{H}-$ $12 \mathrm{~b})$. The ${ }^{13} \mathrm{C}$-NMR displayed 15 carbon resonances and the distortionless enhancement by polarization transfer (DEPT) spectrum was consistent with the presence of a methylene $\left(\delta_{\mathrm{C}} 69.0, \mathrm{C}-12\right)$ bearing a hydroxyl moiety, a quaternary carbon $\left(\delta_{\mathrm{C}} 74.2, \mathrm{C}-11\right)$ bearing a hydroxyl unit, two oxygenated methines $\left(\delta_{\mathrm{C}} 84.5, \mathrm{C}-1 ; 71.8, \mathrm{C}-2\right)$, and two olefinic carbons $\left(\delta_{\mathrm{C}} 107.8, \mathrm{C}-15 ; 149.0, \mathrm{C}-4\right)$, as well as two methyls, four methylenes, two methines, and one quaternary carbon. Based on the above evidence, $\mathbf{1}$ was deduced to be a sesquiterpenoid with an eudesmane-type skeleton. ${ }^{6-8)}$ In the heteronuclear multiple bond connectivity (HMBC) spectrum of 1 (Fig. 1), the long-range correlations from $\mathrm{H}-15 \mathrm{a}$ to $\mathrm{C}-4$, from $\mathrm{H}-15 \mathrm{~b}$ to $\mathrm{C}-4$, from $\mathrm{H}-3$ to $\mathrm{C}-15$, and from $\mathrm{H}-5$ to $\mathrm{C}-15$ revealed the presence of a double bond across C-4/C- 15 , while correlations from $\mathrm{H}-12$ to $\mathrm{C}-7$ and from $\mathrm{H}-13$ to $\mathrm{C}-7$ demonstrated that a propane-1,2-diol moiety was attached to C-7. Based on the above data and comprehensive 2D NMR experiments $\left({ }^{1} \mathrm{H}-{ }^{1} \mathrm{H}\right.$ COSY, HMQC, HMBC), the structure of $\mathbf{1}$ was established as shown in Fig. 1. The relative stereochemistry of the chiral centers in $\mathbf{1}$ was resolved by 2D ROESY data. In the ROESY spectrum (Fig. 1), cross peaks were observed from $\mathrm{H}_{3}-14$ to $\mathrm{H}-2$, from $\mathrm{H}-1$ to $\mathrm{H}-5$, and from $\mathrm{H}-5$ to H-7. Thus $\mathrm{H}_{3}-14$ and $\mathrm{H}-2$ were on the same molecular plane ( $\alpha$-configuration) while $\mathrm{H}-1, \mathrm{H}-5$, and $\mathrm{H}-7$ were on the opposite side of the molecular plane ( $\beta$-configuration).

Compound $\mathbf{2}$ was isolated as a pale yellow lamellar crystal. The HR-FAB mass spectrum showed a quasi-molecular ion peak $[\mathrm{M}+\mathrm{H}]^{+}$at $\mathrm{m} / \mathrm{z} 249.1491$, corresponding to the molecular formula $\mathrm{C}_{15} \mathrm{H}_{20} \mathrm{O}_{3}$. The IR spectrum showed the presence of a hydroxyl group $\left(3412 \mathrm{~cm}^{-1}\right)$, lactone moiety $\left(1743 \mathrm{~cm}^{-1}\right)$, and benzene ring $\left(1614,1508,1463 \mathrm{~cm}^{-1}\right)$. The ${ }^{13} \mathrm{C}$-NMR and DEPT spectra showed 12 carbon resonances including three tertiary methyls, two methylenes, two methines, and five quaternary carbons. The ${ }^{1} \mathrm{H}-$ and ${ }^{13} \mathrm{C}-\mathrm{NMR}$ signals $\left(\delta_{\mathrm{H}} 1.42,3 \mathrm{H}, \mathrm{s}, \mathrm{H}-13 ; 1.55,3 \mathrm{H}, \mathrm{s}, \mathrm{H}-14 ; \delta_{\mathrm{C}} 175.8, \mathrm{C}-\right.$ $2 ; 34.5, \mathrm{C}-3 ; 46.1, \mathrm{C}-4 ; 86.7, \mathrm{C}-5 ; 21.6, \mathrm{C}-13 ; 27.0, \mathrm{C}-14)$ indicated the presence of a $\gamma, \gamma$-dimethyl- $\gamma$-lactone ring. Furthermore, the signals $\left(\delta_{\mathrm{H}} 6.52,2 \mathrm{H}, \mathrm{s}, \mathrm{H}-9\right.$ and $\mathrm{H}-11 ; \delta_{\mathrm{C}}$ 127.7, C-7; 137.5, C-8 and C-12; 115.5, C-9 and C-11; 153.7, C-10; 20.4, C-15 and C-16) were assigned to a symmetric 1,2,4,6-tetrasubstituted benzene ring. Additionally, observation of the cross peaks in the HMBC spectrum from H-6 to C-3, C-7, and C-12, suggested that the aromatic ring moiety was connected to the $\gamma, \gamma$-dimethyl- $\gamma$-lactone uint through $\mathrm{C}-6$. Further analyses of ${ }^{1} \mathrm{H}-{ }^{1} \mathrm{H}$ COSY, HMQC and HMBC spectra (Fig. 2) established the NMR assignments for 2. The relative stereochemistry of the asymmetric center in compound $\mathbf{2}$ was firmly established from the ROESY spec-
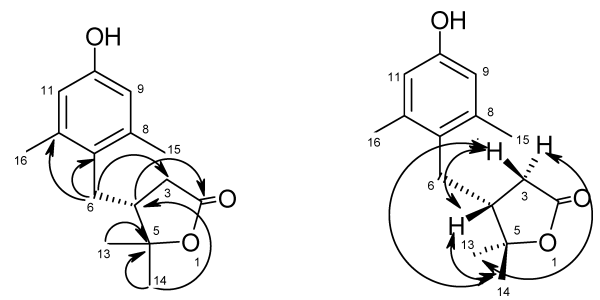

Fig. 2. Key HMBC and ROESY Correlations of $\mathbf{2}$

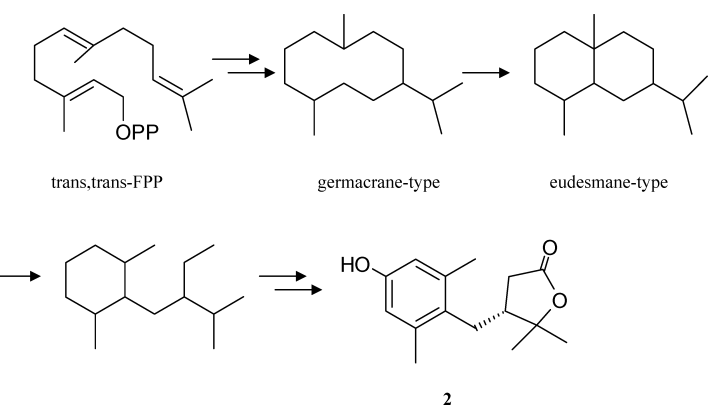

Chart 1. The Possible Biogenetic Pathway Proposed for Lyratol D (2)<smiles>C=C1CC(O)C(O)[C@@]2(C)CCC(C(C)(O)CO)CC12</smiles><smiles>Cc1cc(O)cc(C)c1C[C@H]1CC(=O)OC1(C)C</smiles>

1 2
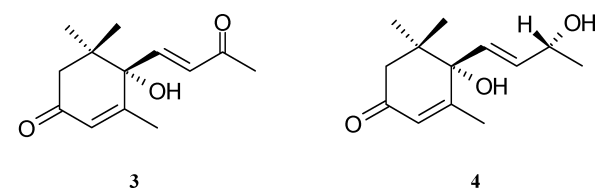

Chart 2. The Structures of Compounds $(\mathbf{1}-\mathbf{4})$ Isolated from Solanum lyratum

trum (Fig. 2). In the ROESY experiment, the NOE correlations between $\mathrm{H}-4 / \mathrm{H}-14, \mathrm{H}-4 / \mathrm{H}-3\left(\delta_{\mathrm{H}} 2.17\right), \mathrm{H}-4 / \mathrm{H}-6 \mathrm{~b}\left(\delta_{\mathrm{H}}\right.$ $2.51), \mathrm{H}-14 / \mathrm{H}-3\left(\delta_{\mathrm{H}} 2.17\right), \mathrm{H}-13 / \mathrm{H}-3\left(\delta_{\mathrm{H}} 2.54\right)$, and H-13/H$6 \mathrm{a}\left(\delta_{\mathrm{H}} 2.64\right)$ indicated the $\beta$-orientations of $\mathrm{H}-4, \mathrm{H}-14$ and $\mathrm{H}-3\left(\delta_{\mathrm{H}} 2.17\right)$ and the $\alpha$-orientations of $\mathrm{H}-13$ and $\mathrm{H}-3\left(\delta_{\mathrm{H}}\right.$ 2.54). From the above data, the structure of compound 2 was represented as shown in Fig. 2, named lyratol D.

A possible biogenetic pathway for lyratol D (2) is shown in Chart 1. The biogenetic origin of lyratol D seems to be a eudesmane-type sesquiterpenoid, which would be transformed into lyratol D by enzyme reactions, such as oxidation and ring opening.

Phytochemical studies of this plant also resulted in the isolation of two known constituents: dehydrovomifoliol (3; Chart 2) $\left([\alpha]_{\mathrm{D}}^{25}+221.6^{\circ}, c=0.49, \mathrm{CH}_{2} \mathrm{Cl}_{2}\right)$ and blumenol $\mathrm{A}$ (4) Chart 2) $\left([\alpha]_{\mathrm{D}}^{25}+99.8^{\circ}, c=0.65, \mathrm{CHCl}_{3}\right)$. Two known compounds were identified by comparison of their physical and spectral data $\left([\alpha]_{\mathrm{D}},{ }^{1} \mathrm{H}-\mathrm{NMR},{ }^{13} \mathrm{C}-\mathrm{NMR}, \mathrm{MS}\right)$ with reported values.

The four isolated compounds $(\mathbf{1}-\mathbf{4})$ were evaluated for their cytotoxic activities against HONE-1, KB, and HT29 
Table 2. Cytotoxicity of Compounds $\mathbf{1}-\mathbf{4}$ against Cultured HONE-1, KB and HT29 Cancer Cell Lines

\begin{tabular}{cccc}
\hline \hline \multirow{2}{*}{ Compounds } & \multicolumn{2}{c}{ Growth inhibition constant $\left(\mathrm{IC}_{50}\right)^{a)}[\mu \mathrm{M}]$} \\
\cline { 2 - 4 } & HONE-1 & $\mathrm{KB}$ & HT29 \\
\hline Etoposide $^{b)}$ & $0.6 \pm 0.4$ & $0.9 \pm 0.3$ & $1.9 \pm 0.6$ \\
Cisplatin $^{b)}$ & $3.8 \pm 0.4$ & $4.5 \pm 0.7$ & $5.8 \pm 1.2$ \\
$\mathbf{1}$ & $3.7 \pm 2.1$ & $6.1 \pm 2.4$ & $6.5 \pm 1.6$ \\
$\mathbf{2}$ & $5.6 \pm 3.0$ & $8.1 \pm 1.8$ & $6.4 \pm 2.3$ \\
$\mathbf{3}$ & $4.8 \pm 1.2$ & $4.0 \pm 1.9$ & $5.7 \pm 2.1$ \\
$\mathbf{4}$ & $4.3 \pm 1.5$ & $3.9 \pm 2.0$ & $6.0 \pm 3.1$ \\
\hline
\end{tabular}

a) $\mathrm{IC}_{50}$ is defined as the concentration that resulted in a $50 \%$ decrease in cell number and the results are means \pm standard deviation of three independent replicates. The $\mathrm{IC}_{50}$ greater than $10 \mu \mathrm{M}$ was considered to be no cytotoxicity. b) Positive control substance.

cancer cell lines using the methylene blue dye assay and anticancer drugs etoposide and cisplatin ${ }^{9,10)}$ as positive controls. These sesquiterpenoids exhibited significant cytotoxicity as shown in Table 2.

\section{Experimental}

General Experimental Procedures Melting points were determined on an XT-4 micro-melting point apparatus and are uncorrected. Optical rotations were measured on a Perkin-Elmer 241 polarimeter. UV spectra were obtained on a Shimadzu UV-160 spectrophotometer. IR spectra were run on a Perkin-Elmer 683 infrared spectrometer with $\mathrm{KBr}$ disks. FAB-MS and HRFAB-MS were recorded on an Autospec-Ultima ETOF MS spectrometer. NMR spectra were obtained with a Varian Unity BRUKER 400 at $400 \mathrm{MHz}$ $\left({ }^{1} \mathrm{H}\right)$ and $100 \mathrm{MHz}\left({ }^{13} \mathrm{C}\right)$, with TMS as the internal standard. Silica gel (200-300 mesh, 40-75 $\mu \mathrm{m}$ ) for column chromatography and silica gel GF254 for preparative TLC were obtained from Qingdao Marine Chemical Factory, Qingdao, China.

Plant Material Solanum lyratum THunB was collected in Linyi district, Shandong Province, People's Republic of China, in September 2006, and identified by Professor Yan-yan Zhao, School of Pharmaceutical Science, Yantai University. The whole plants of S. lyratum were harvested and airdried at room temperature in the dark. A voucher specimen (YP06089) has been deposited at the Herbarium of the School of Pharmaceutical Science, Yantai University.

Extraction and Isolation The air-dried whole plant $(10.0 \mathrm{~kg})$ of Solanum lyratum was finely cut and extracted three times $(1 \mathrm{~h} \times 3)$ with refluxing EtOH. Evaporation of the solvent under reduced pressure provided the ethanolic extract. The extract was dissolved and suspended in $\mathrm{H}_{2} \mathrm{O}$, and partitioned with $\mathrm{CHCl}_{3}$, EtOAc, and $n-\mathrm{BuOH}$. The $\mathrm{CHCl}_{3}$ fraction $(217.1 \mathrm{~g})$ was subjected to column $(10 \times 120 \mathrm{~cm})$ chromatography over silica gel $(200-300 \mathrm{mesh}, 3.0 \mathrm{~kg})$ and eluted with cyclohexane-acetone [95:5 (6.01), $90: 10$ (6.01), $85: 15$ (6.01), $80: 20$ (7.01), $75: 25$ (7.01), $70: 30$ (7.01), $60: 40(5.01)$ and $50: 50(3.01)]$ to give ten fractions. Fraction $4(3.9 \mathrm{~g})$ was isolated by $\mathrm{CC}$ over silica gel (cyclohexane-EtOAc stepwise gradient start- ing with 10:1 ratio) and separated by preparative TLC $\left(\mathrm{CHCl}_{3}-\mathrm{CH}_{3} \mathrm{COCH}_{3}\right.$, $10: 1, \mathrm{v} / \mathrm{v})$ to afford $2(32 \mathrm{mg}), 3(15 \mathrm{mg})$, and $4(9 \mathrm{mg})$; Fraction $8(2.6 \mathrm{~g})$ was separated by reversed-phase silica gel $(100 \mathrm{~g}, 40-50 \mu) \mathrm{CC}$ [eluted by $\left.\mathrm{MeOH}-\mathrm{H}_{2} \mathrm{O}, 45 / 55, \mathrm{v} / \mathrm{v}\right]$ and purified on Sephadex LH-20 [100 g, eluting with $\mathrm{CHCl}_{3}-\mathrm{CH}_{3} \mathrm{OH}, 10: 40$, v/v] to give 1 (11 mg).

Lyratol C (1): Colorless prismatic crystal, mp $207-208^{\circ} \mathrm{C},[\alpha]_{\mathrm{D}}^{25}+9.8^{\circ}$ $\left(c=0.82, \mathrm{CHCl}_{3}\right)$. IR (KBr) $v_{\max }: 3405,2930,1651,1381,1050$ and $897 \mathrm{~cm}^{-1}$. FAB-MS $m / z: 271.3[\mathrm{M}+\mathrm{H}]^{+}$. HR-FAB-MS $m / z: 271.1909$ $[\mathrm{M}+\mathrm{H}]^{+}\left(\mathrm{Calcd}\right.$ for $\left.\mathrm{C}_{15} \mathrm{H}_{27} \mathrm{O}_{4}, 271.1904\right) .{ }^{1} \mathrm{H}$ - and ${ }^{13} \mathrm{C}-\mathrm{NMR}$ data, see Table 1.

Lyratol D (2): Pale yellow lamellar crystal, mp $164-165^{\circ} \mathrm{C},[\alpha]_{\mathrm{D}}^{25}$ $-22.5^{\circ}\left(c=0.93, \mathrm{CHCl}_{3}\right)$. UV $(\mathrm{MeOH}) \lambda_{\max }(\log \varepsilon): 221$ (3.54) and 262 (4.24) nm. IR (KBr) $v_{\max }: 3412,2984,1743,1614,1508$ and $1463 \mathrm{~cm}^{-1}$. FAB-MS $m / z: 249.2[\mathrm{M}+\mathrm{H}]^{+}$. HR-FAB-MS $m / z: 249.1491[\mathrm{M}+\mathrm{H}]^{+}(\mathrm{Calcd}$ for $\left.\mathrm{C}_{15} \mathrm{H}_{21} \mathrm{O}_{3}, 249.1485\right)$. ${ }^{1} \mathrm{H}$ - and ${ }^{13} \mathrm{C}$-NMR data, see Table 1 .

Antitumoral Cytotoxic Bioassays Human nasopharyngeal carcinoma HONE-1, oral epidermoid carcinoma KB, and colorectal carcinoma HT29 cells were maintained in RPMI-1640 medium supplied with 5\% fetal bovine serum. Cells in logarithmic phase were cultured at a density of 50000 cells $/ \mathrm{ml}$ per well in a 24 -well plate. The cells were exposed to various concentrations of the test drugs for $72 \mathrm{~h}$. The methylene blue dye assay was used to evaluate the effects of the tested drugs on cell growth, as described previously. ${ }^{11)}$ The $\mathrm{IC}_{50}$ value resulting from $50 \%$ inhibition of cell growth was calculated graphically as a comparison with the control.

Acknowledgements We are grateful to Mr. Ji-Yong Chen and Ms. Hong $\mathrm{Yu}$ (School of Pharmaceutical Science, Yantai University) for the measurement of FAB-MS, HR-FAB-MS, UV, IR, and NMR spectra, respectively. We also gratefully acknowledge Mr. Zhen Li (School of Pharmaceutical Science, Yantai University) for the bioactivity screenings.

\section{References}

1) Cao J.-Y., Tan X.-L., Chin. J. Mod. Appl. Pharm., 5, 1-3 (1988)

2) Kim H. M., Lee E. J., Immunopharmacol. Immunotoxicol., 20, 135 146 (1998).

3) Wu W.-Y., Gao Z.-G., Li Y.-G., Ding Y., World Phytomed., 16, 245 247 (2001).

4) Serra S., Barakat A., Fuganti C., Tetrahedron Asymmetry, 18, 2573 2580 (2007).

5) Gonzalez A. G., Guillermo J. A., Ravelo A. G., Jimenez I. A., J. Nat. Prod., 57, 400-402 (1994).

6) Liu X.-H., Zhao D.-B., Yang C.-R., Wang H.-Q., Chin. Chem. Lett., 11, 1009-1012 (2000).

7) Wang M., Yuan C.-S., Han Y.-F., Jia Z.-J., Chin. Chem. Lett., 13, $1069-1070$ (2002)

8) Mao M.-J., Yuan C.-S., Jia Z.-J., Chin. Chem. Lett., 15, 794-796 (2004).

9) Chang J.-Y., Liu J.-F., Juang S.-H., Liu T.-W., Chen L.-T., Cancer Res., 62, 3716-3721 (2002)

10) Chang C.-I., Kuo C.-C., Chang J.-Y., Kuo Y.-H., J. Nat. Prod., 67, 91-93 (2004)

11) Chang J.-Y., Chang C.-Y., Kuo C.-C., Chen L.-T., Wei Y.-S., Kuo Y.H., Mol. Pharmacol., 65, 77-84 (2004). 